Vol. 7 No. 2 Juli 2018

E-ISSN : 2502-3101 P-ISSN : 2302-528x

http://ojs.unud.ac.id/index.php/jmhu

\title{
Penjatuhan Pidana oleh Hakim Terhadap Prajurit Tentara Nasional Indonesia sebagai Pelaku Penyalahguna Narkotika
}

\author{
Sugiarto $^{1}$
}

${ }^{1}$ Bagian Hukum, KODAM IX Udayana, E-mail: sugik_law@yahoo.co.id

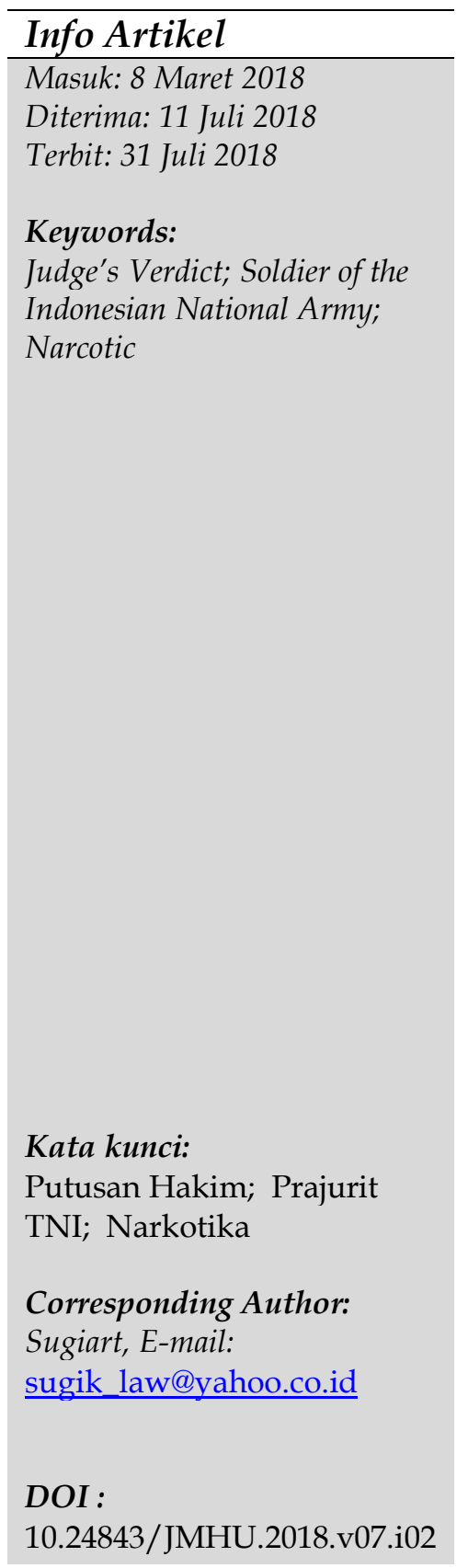

\begin{abstract}
Sanctions stipulated in the Narcotics law adheres to double track system in the form of criminal sanctions and action sanctions. Rehabilitation is one form of action sanction, in accordance with the provisions of Article 54 of Law Number 35 Year 2009 on Narcotics. The purpose of this study is to analyze the judge's consideration in dropping criminal punishment against the soldier of Indonesian National Army as narcotics abusers. This study uses normative research methods with statute approach and case approach. The results of the study indicate that Narcotics addicts and narcotics abuse victims in the case of proven or proven as victims of narcotics abusers as regulated in Article 127 paragraph (3) of Narcotics Law shall undergo medical rehabilitation and social rehabilitation. Consideration of the judges of Military Court III-14 Denpasar through its decree Number: 33-K / PM. III-14 / AD / VIII / 2015, which states that the defendant has been proven legally and convincingly guilty of committing a criminal act of narcotics perpetrator to impose criminal sanctions, appears to be inconsistent with the provisions of the Narcotics Act because the judge does not consider the provisions of Article 127 paragraph (3) Law Number 35 Year 2009, namely compulsory rehabilitation in case it can be proven or proven as a victim of narcotics abuser, the abuser shall undergo medical rehabilitation and social rehabilitation. Therefore, the judge in deciding the perpetrators of narcotics abuse should be guided by the provisions set forth in Law Number 35 Year 2009 on Narcotics.
\end{abstract}

\section{Abstrak}

Sanksi yang diatur dalam undang-undang Narkotika menganut double track system yaitu berupa sanksi pidana dan sanksi tindakan. Rehabilitasi merupakan salah satu bentuk sanksi tindakan, sesuai dengan ketentuan dalam Pasal 54 Undang-Undang Nomor 35 Tahun 2009 tentang Narkotika. Tujuan dari penelitian ini adalah untuk menganalisis tentang pertimbangan Hakim dalam menjatuhkan pidana penjara terhadap prajurit TNI sebagai pelaku penyalah guna narkotika. Studi ini menggunakan metode penelitian normatif dengan pendekatan perundang-undangan dan pendekatan kasus. Hasil studi menunjukkan bahwa Pecandu 


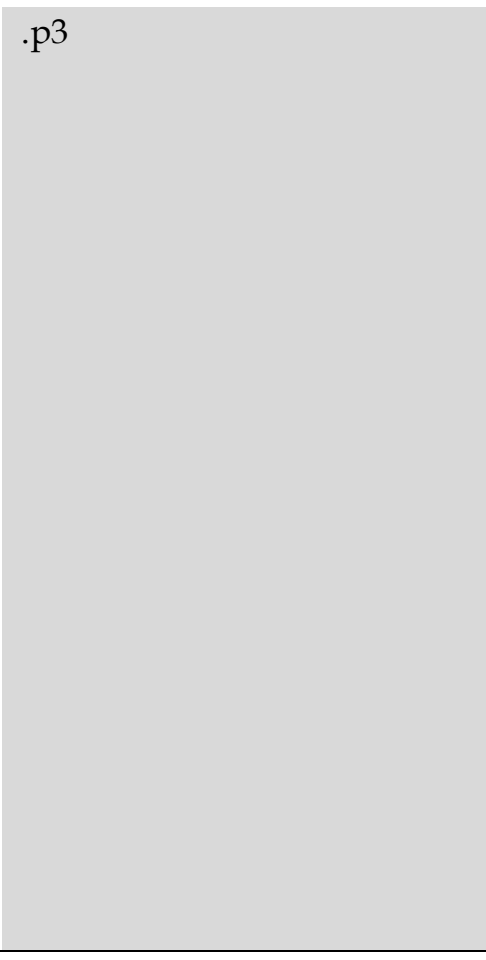

\begin{abstract}
Narkotika dan korban penyalahgunaan narkotika dalam hal dapat dibuktikan atau terbukti sebagai korban penyalahguna narkotika sebagaimana diatur dalam Pasal 127 ayat (3) UU Narkotika wajib menjalani rehabilitasi medis dan rehabilitasi sosial. Pertimbangan hakim Pengadilan Militer III-14 Denpasar melalui putusannya Nomor :33-K/ PM. III14/AD/ VIII /2015, yang menyatakan terdakwa telah terbukti secara sah dan meyakinkan bersalah melakukan tindak pidana penyalahguna narkotika menjatuhkan sanksi pidana, tampak tidak sesuai dengan ketentuan dalam Undang- tentang Narkotika karena hakim tidak memperhatikan ketentuan Pasal 127 ayat (3) UndangUndang Nomor 35 Tahun 2009, yaitu wajib rehabilitasi dalam hal dapat dibuktikan atau terbukti sebagai korban penyalahguna narkotika, penyalahguna tersebut wajib menjalani rehabilitasi medis dan rehabilitasi sosial. Oleh karena itu hakim dalam menjatuhkan putusan terhadap pelaku penyalah guna narkotika harus berpedoman pada ketentuan yang sudah diatur dalam Undang-Undang Nomor 35 Tahun 2009 tentang Narkotika.
\end{abstract}

\title{
1. Pendahuluan
}

Narkotika di Indonesia beredar tidak hanya di kota-kota besar, saat ini sudah sampai ke daerah-daerah pedesaan dan bahkan daerah terpencil seperti wilayah-wilayah perbatasan Negara maupun wilayah terpencil lainnya. Banyak pihak yang berpendapat bahwa Indonesia merupakan pasar gelap (black market) bagi peredaran narkoba yang dijalankan oleh jaringan sindikat narkoba lokal maupun Internasional. Pintu masuk narkoba ke Indonesia amat terbuka dan dapat dari berbagai sisi serta banyak jumlahnya, baik itu melalui darat, laut maupun udara. Kejahatan di bidang narkotika dan obat-obatan terlarang (Narkoba) ini modus operansinya mengikuti dan memanfaatkan perkembangan Ilmu Pengetahuan dan Teknologi (IPTEK). Perkembangan dan kemajuan arus globalisasi seperti informasi dan teknologi komunikasi dimanfatan secara maksimal oleh sindikat atau jaringan mafia narkotika ini. Tidak salah label yang di berikan untuk tipe kejahatan yang luar biasa (extra ordinary crime), sebagai kejahatan terorganisasi (organized crime), kejahatan terselubung (hidden crime), kejahatan lintas batas Negara (transnational crime). ${ }^{1}$

Penyalahgunaan narkotika ini bukan saja merupakan masalah yang perlu mendapat perhatian bagi negara Indonesia, melainkan juga bagi dunia Internasional. Memasuki abad ke-20 perhatian dunia internasional terhadap masalah narkotika semakin meningkat, salah satu dapat dilihat melalui Single Convention on Narcotic Drugs pada tahun 1961. ${ }^{2}$ Masalah ini menjadi begitu penting mengingat bahwa obat-obat (narkotika) itu adalah suatu zat yang dapat merusak fisik dan mental yang

1 Artha, I. G., \& Wiryawan, I. W. (2015). Pengendalian Peredaran Gelap Narkotika Oleh Narapidana Dari Dalam Lembaga Pemasyarakatan (Lapas). Jurnal Magister Hukum Udayana (Udayana Master Law Journal). 4(3). h. 589

2 Adi, K. (2009). Kebijakan Kriminal dalam penanggulangan tindak pidana narkotika oleh anak. UMM Press. Malang. h. 30 
bersangkutan, apabila penggunanya tanpa resep dokter. Dampak dari penyalahgunaan narkotika adalah dapat berakibat pada pengguna itu sendiri dan pada masyarakat pada umumnya. Bagi individu akan membawa dampak yang merugikan bagi kesehatan baik kesehatan rohani maupun jasmani. Sedangkan bagi masyarakat akan berdampak kemerosotan moral dan meningkatnya kriminalitas.

Pemerintah Indonesia telah meratifikasi United Nation Convention Againts Illicit Traffic on Narcotic Drugs and Psychotropic Substances, 1988 yaitu bertujuan untuk menyelamatkan bahaya laten narkoba dan menyelamatkan rakyat Indonesia terutama generasi muda dari penyalahgunaan narkotika serta untuk menangkis tudingan miring dari masyarakat internasional, dengan di berlakunya Undang-Undang Nomor 7 Tahun 1997 tentang Psikotrofika dan Undang-Undang Nomor 22 Tahun 1997 tentang Narkotika yang dalam perkembangannya selanjutnya memberlakukan UndangUndang Nomor 35 Tahun 2009 tentang Narkotika (UU Narkotika) setelah menyatakan Undang-Undang Nomor 22 Tahun 1997 tidak berlaku lagi.

Peredaran gelap narkotika kini mampu menyentuh dan merambah seluruh lapisan masyarakat mulai dari pelajar, mahasiswa, kalangan profesional, selebritis, birokrat bahkan penegak hukum, maupun prajurit TNI yang merupakan komponen utama dalam pertahanan negara, dan merupakan alat negara yang bertugas mempertahankan, melindungi, dan memelihara keutuhan dan kedaulatan negara. Prajurit TNI yang melakukan pelanggaran hukum harus diselesaikan sesuai ketentuan hukum yang berlaku, dalam hal ini tindakan yang dilakukan merupakan suatu tindak pidana, harus diselesaikan menurut mekanisme yang berlaku tanpa diskriminasi, dengan menjungjung nilai-nilai keadilan diatas landasan setiap orang diperlakukan sama di muka hukum. ${ }^{3}$ Menurut Molejatno bahwa tindak pidana merupakan perbuatan yang dilarang oleh suatu aturan hukum, larangan disertai ancaman (sanksi) yang berupa pidana tertentu bagi siapa yang melanggar larangan tersebut. ${ }^{4}$

Sanksi yang diatur dalam UU Narkotika menganut double track system yaitu berupa sanksi pidana dan sanksi tindakan. ${ }^{5}$ Rehabilitasi merupakan salah satu bentuk sanksi tindakan, sesuai dengan ketentuan dalam Pasal 54 UU Narkotika disebutkan bahwa Pecandu Narkotika dan korban penyalahgunaan narkotika wajib menjalani rehabilitasi medis dan rehabilitasi sosial. Rehabilitasi terhadap pecandu narkotika adalah suatu proses pengobatan untuk membebaskan pecandu dari ketergantungan, dan masa menjalani rehabilitasi tersebut diperhitungkan sebagai masa menjalani hukuman. Rehabilitasi terhadap pecandu narkotika juga merupakan suatu bentuk perlindungan sosial yang mengintegrasikan pecandu narkotika ke dalam tertib sosial agar dia tidak lagi melakukan penyalahgunaan narkotika. ${ }^{6}$ Upaya rehabilitasi meskipun cukup rumit namun penting untuk dilakukan untuk bisa mengembalikan korban penyalahgunaan

${ }^{3}$ Atmasasmita, R. (2010). Sistem Peradilan Pidana Kontemporer. Kencana Prenada Media Grup. Jakarta. h. 82

4 Amrani, H., \& Ali, M. (2015). Sistem Pertanggungjawaban Pidana Perkembangan dan Penerapan. Raja Grafindo Persada. Jakarta. h. 15

${ }^{5}$ Krisnawati, D. \& Utami, S. B. (2014) Pelaksanaan rehabilitasi bagi Pecandu Narkotika Pada Tahap Penyidikan Pasca BERLAKUNYA Peraturan Bersama 7 (tujuh) Lembaga Negara Republik Indonesia. Laporan Hasil Penelitian Universitas Gadjah Mada. Yogyakarta. h. 4

${ }^{6}$ Gani, H. A. (2015). Rehabilitasi Sebagai Upaya Depenalisasi Bagi Pecandu Narkotika, tersedia di https://media.neliti.com/media/publications/35561-ID-rehabilitasi-sebagai-upaya depenalisasi-bagi-pecandu-narkotika, di akses pada tanggal 25 Agustus 2017 
norkotika berada kembali di tengah-tengah masyarakat. Salah satu kesulitan dan kerumitan upaya rehabilitasi adalah masih adanya post addiction syndrome. ${ }^{7}$ Sesungguhnya pemerintah melalui BNN telah mencanangkan program pencegahan dan pemberantasan penyalahgunaan narkoba. Penyalahguna narkoba direhabilitasi secara bertahap baik rehabilitasi medis maupun sosial. 8 Studi dari juga mengemukakan pentingnya dilakukan rehabilitasi secara medis dan social bagi korban penyalahgunaan narkotika. ${ }^{9}$

Pasal 127 ayat (3) UU Narkotika menentukan, dalam hal penyalahguna dimaksud pada ayat (1) dapat dibuktikan atau terbukti sebagai korban penyalahguna narkotika, penyalahguna tersebut wajib menjalani rehabilitasi medis dan rehabilitasi sosial. Sebagaimana dalam penjelasan Pasal 54 UU Narkotika, yang dimaksud dengan korban penyalagunaan narkotika adalah seseorang yang tidak sengaja menggunakan narkotika karena dibujuk, diperdaya, ditipu, dipaksa, dan/atau diancam untuk menggunakan narkotika. Seseorang dinyatakan sebagai korban penyalahgunaan narkotika, dibuktikan berdasarkan pakta dipersidangan yang terungkap apakah seseorang sebagai korban penyalahgunaan narkotika atau tidak. Dengan dapat dibuktikanya korban penyalahgunaan narkotika, maka korban penyalahgunaan narkotika tersebut wajib menjalani rehabilitasi medis dan rehabilitasi sosial sebagaimana diatur dalam UU Narkotika.

Hakim dalam kenyataannya seringkali tidak memberikan hak kepada pengguna narkotika untuk melaksanakan rehabilitasi, walaupun dalam UU Narkotika ada jaminan rehabilitasi bagi pecandu narkotika dan korban penyalahgunaan narkotika. ${ }^{10}$ Hakim sebagai corong undang-undang tidak mempertimbangkan ketentuan tersebut, sebagaimana dalam Putusan Pengadilan Militer III-14 Denpasar Nomor : 33-K/ PM.III14/AD/VIII/ 2015 tanggal 17 November 2015 yang menyatakan terdakwa yaitu Satriya Wira Yudha, Serda NRP 21120131370492, telah terbukti secara sah dan meyakinkan bersalah melakukan tindak pidana "Penyalah Guna Narkotika Golongan 1 bagi diri sendiri". Sebagai mana diatur dalam pasal 127 ayat (1) huruf (a) Undang-Undang Nomor 35 Tahun 2009 tentang Narkotika, memidana Terdakwa dengan pidana penjara selama 10 (sepuluh) bulan.

Hakim pada dasarnya bebas untuk menafsirkan ketentuan undang-undang terhadap suatu permasalahan hukum yang diperhadapkan kepada hakim didepan pengadilan termasuk di dalamnya kewenangan untuk menjatuhkan pidana penjara terhadap pelaku tindak pidana penyalah gunaan Narkotika. Hakim dalam mengadili setiap perkara yang ditangani di persidangan dan dihubungkan dengan penerapan dasar

7 Eleanora, F. N. (2018). Bahaya Penyalahgunaan Narkoba Serta Usaha Pencegahan Dan Penanggulangannya (Suatu Tinjauan Teoritis). Jurnal hukum, 25(1), h. 450.

8 Sholihah, Q. (2015). Efektivitas Program P4GN Terhadap Pencegahan Penyalahgunaan NAPZA. Jurnal Kesehatan Masyarakat, 10(2), h. 154.

9 Isnaini, Y., Hariyono, W., \& ken Utami, I. (2013). Hubungan antara dukungan keluarga dengan keinginan untuk sembuh pada penyalahguna NAPZA di lembaga pemasyarakatan wirogunan kota yogyakarta. Kes Mas: Jurnal Fakultas Kesehatan Masyarakat, 5(2), h. 161.

${ }^{10}$ Hikmawati, P. (2011) Analisis Terhadap Sanksi Pidana Bagi Pengguna Narkotika. Peneliti Madya Bidang Hukum Pidana pada Pusat Pengkajian Pengolahan Data dan Informasi (P3DI) Setjen DPR RI. Jakarta. h. 343 
hukum yang jelas, hal ini sesuai asas hukum pidana yaitu asas legalitas yang diatur pada Pasal 1 ayat (1) KUHP yaitu hukum pidana harus bersumber pada undangundang. Tujuan pengadilan tidaklah semata-mata memidana orang-orang yang bersalah melakukan tindak pidana, tetapi juga mempunyai tujuan mendidik agar yang bersangkutan dapat kembali ke jalan yang benar menjadi warga negara yang baik.

Berangkat dari latar belakang di atas, menarik untuk di kaji mengenai apakah pertimbangan hakim dalam putusan Nomor : 33-K/ PM.III-14 / AD / VIII / 2015 yang menjatuhkan pidana penjara terhadap prajurit TNI sebagai pelaku penyalah guna narkotika sudah sesuai dengan Undang-Undang Nomor 35 Tahun 2009 tentang Narkotika?

Penelitian ini merupakan karya ilmiah asli yang belum diteliti sebelumnya. Adapun karya ilmiah yang terkait dengan karya ilmiah penulis tentang Analisis Yuridis Penjatuhan Pidana Oleh Hakim Terhadap Prajurit TNI Sebagai Pelaku Penyalah Guna Narkotika (Studi Putusan Nomor : 33-K/ PM.III-14/AD/VIII/2015) yaitu karya ilmiah dari Ida Bagus Putu Swadharma Diputra tahun 2012 dalam judul Kebijakan Rehabilitasi Terhadap Penyalahgunaan Narkotika Pada Undang-Undang Nomor 35 Tahun 2009 tentang Narkotika yang rumusan masalahnya adalah Bagaimana perumusan kebijakan rehabilitasi dalam Undang-Undang Nomor 35 Tahun 2009 tentang Narkotika ?..11 Karya ilmiah lainya yang terkait yaitu A.A. Istri Mas Candra Dewi tahun 2012 dengan judul Perlindungan Hukum Terhadap Korban Penyalahgunaan Narkotika Dengan Berlakunya Undang-Undang Nomor 35 Tahun 2009 tentang Narkotika yang rumusan masalahnya adalah bagaimana pengawasan terhadap putusan rehabilitasi terhadap korban penyalahgunaan narkotika dengan berlakunya Undang-Undang Nomor 35 Tahun 2009 tentang Narkotika ?. ${ }^{12}$ Jelas nampak perbedaan karya ilmiah tersebut dengan karya ilmiah yang dibuat oleh Penulis. Adapun keunggulan karya ilmiah ini dari karya ilmiah lainnya yaitu membahas lebih dalam tentang pertimbangan Hakim dalam menjatuhkan pidana pejara terhadap prajurit TNI sebagai pelaku penyalahguna narkotika apakah sudah sesuai dengan Undang-Undang Nomor 35 Tahun 2009 tentang Narkotika. Tujuan dari penelitian ini adalah untuk menganalisis tentang pertimbangan Hakim dalam menjatuhkan pidana penjara terhadap prajurit TNI sebagai pelaku penyalah guna narkotika apakah sudah sesuai dengan Undang-Undang Nomor 35 Tahun 2009 tentang Narkotika.

\section{Metode Penelitian}

Jenis penelitian yang dipergunakan dalam tulisan penelitian ini adalah penelitian hokum normatif. Dalam penelitian hukum normatif dapat dipahami bahwa penelitian dilakukan dengan meletakan hukum sebagai sistem norma. Sistem norma yang di maksud adalah mengenai asas-asas, norma, kaidah dari peraturan perundang-

11 Diputra, I. B. P. S. (2013). Kebijakan Rehabilitasi Terhadap Penyalah Guna Narkotika Pada Undang-Undang Nomor 35 Tahun 2009 Tentang Narkotika. Jurnal Magister Hukum Udayana (Udayana Master Law Journal). 2(1).

12 Dewi, C., \& Mas, A. I. (2012). Perlindungan Hukum terhadap Korban Penyalahguna Narkotika dengan Berlakunya Undang-undang Nomor 35 Tahun 2009 Tentang Narkotika. Jurnal Magister Hukum Udayana, 1(1). 
undangan, putusan pengadilan, perjanjian serta doktrin. ${ }^{13}$ Pendekatan dalam penelitian ini menggunakan pendekatan Perundang-undangan (statute approach) dan pendekatan konseptual (conseptual approach).

\section{Hasil dan Pembahasan}

\subsection{Kedudukan Hukum Pengguna Narkotika Dalam Undang-Undang Nomor 35 Tahun 2009 tentang Narkotika}

Penggunaan istilah pengguna narkotika untuk memudahkan dalam penyebutan bagi orang yang menggunakan narkotika dan untuk membedakan dengan penanam, produsen, penyalur, kurir dan pengedar narkotika. Apabila dikatkan dengan orang yang menggunakan narkotika, dalam Pasal 1 UU Narkotika dapat ditemukan berbagai istilah yaitu:

a. Pecandu Narkotika adalah orang yang menggunakan atau menyalahgunakan narkotika dan dalam keadaan ketergantungan pada narkotika, baik secara fisik maupun psikis.

b. Penyalah Guna adalah orang yang menggunakan narkotika tanpa hak atau melawan hukum.

c. Korban penyalahgunaan narkotika adalah seseorang yang tidak sengaja menggunakan narkotika karena di bujuk, diperdaya, ditipu, dipaksa, dan/atau diancam untuk menggunakan narkotika.

d. Mantan Pecandu Narkotika adalah orang yang telah sembuh dari ketergantungan terhadap narkotika secara fisik maupun pisikis.

Melihat istilah tersebut diatas, dapat dilihat antara penyalahgunaan dan peredaran narkotika memang sulit dipisahkan namun hal tersebut tidak dapat disamakan dan upaya penanggulangannya juga harus dibedakan. Hal tersebut selaras dengan amanat tujuan UU Narkotika sebagaimana tercantum dalam Pasal 4 yang menyatakan bahwa UU Narkotika bertujuan:

a. Menjamin ketersediaan narkotika untuk kepentingan pelayanan kesehatan dan/atau pengembangan ilmu pengetahuan dan teknologi.

b. Mencegah, melindungi dan menyelamatkan bangsa Indonesia dari penyalahgunaan narkotika.

c. Memberantas peredaran gelap narkotika dan perkusor narkotika.

d. Menjamin pengaturan rehabilitasi medis dan sosial bagi penyalah guna dan pencandu narkotika.

Sebagaimana disebutkan dalam tujuan UU Narkotika diatas, adanya jaminan pengaturan upaya rehabilitasi bagi pengguna narkotika, dimana ketentuan tersebut dipertegas dalam ketentuan Pasal 54 UU Narkotika yang menegaskan bahwa pecandu dan korban penyalahgunaan narkotika wajib menjalani rehabilitasi medis dan rehabilitasi sosial. Perumusan sanksi terhadap tindak pidana penyalahgunaan narkotika mengacu pada double track system, artinya sanksi yang dapat dikenakan terhadap tindak pidana narkotika tidak hanya terbatas pada sanksi pidana, namun dapat pula dikenakan sanksi tindakan. Sanksi tindakan yang dimaksud yakni sanksi

13 Salim, H. S., \& Nurbani, E. S. (2014). Penerapan Teori Hukum Pada Penelitian Disertasi dan Tesis. PT Raja Grafindo Persada, Jakarta. h. 13 
rehabilitasi yang ditunjukkan khusus bagi pencandu narkotika. ${ }^{14}$ Double track system dalam perumusan sanksi terhadap tindak pidana penyalahgunaan narkotika adalah paling tepat, karena berdasarkan victimology bahwa pecandu narkotika adalah sebagai self victimizing victims yaitu korban sebagai pelaku, victimology tetap menempatkan penyalahguna narkotika sebagai korban, meskipun dari tindakan pidana/kejahatan yang dilakukan sendiri. ${ }^{15}$

Penjatuhan pidana terhadap penyalahgunaan narkotika bukanlah jawaban sempurna untuk pemberantasan penyalahgunaan narkotika di kalangan penyalahgunannya. Sebagian besar dari narapidana dan tahanan kasus narkoba adalah termasuk kategori pemakai atau bahkan korban yang jika dilihat dari aspek kesehatan, mereka sesungguhnya orang-orang yang menderita sakit. Oleh karena itu, memenjarakan para pemakai atau korban penyalahgunaan narkoba bukanlah sebuah langkah yang tepat karena telah mengabaikan kepentingan perawatan dan pengobatan. ${ }^{16}$

\subsection{Pertimbangan Hakim Dalam Putusan Nomor : 33-K/PM. III-14/ AD/VIII/2015 Yang Menjatuhkan Pidana Pejara Terhadap Prajurit TNI Sebagai Pelaku Pengguna Narkotika di Tinjau dari Undang-Undang Nomor 35 Tahun 2009 tentang Narkotika}

Mengenai sistem peradilan pidana Indonesia sudah pasti tidak dapat terlepas dari pengaruh kekuasaan kehakiman, dimana bukan berarti kekuasaan kehakiman hanya berupa kekuasaan mengadili yaitu kekuasaan menegakkan hukum di badan-badan pengadilan saja, akan tetapi juga mencakup kekuasaan menegakkan hukum dalam seluruh proses penegakan hukum. ${ }^{17}$ Lembaga peradilan sebagai lembaga penegak hukum dalam sistem peradilan pidana merupakan suatu tumpuan harapan dari para pencari keadilan. Hakim mempunyai suatu peran yang sangat penting dalam penegakan hukum pidana untuk tercapainya suatu keadilan yang diharapkan dan dicita-citakan. ${ }^{18}$

Pemidanaan terhadap pelaku pengguna narkoba tidak dapat dipisahkan dari sistem pemidanaan yang diatur oleh sistem hukum di Indonesia. Tujuan dari sistem pemidanaan pada hakikatnya merupakan operasionalisasi penegakan hukum yang dijalani oleh sistem peradilan berdasarkan perangkat hukum yang mengatur berupa kriminalisasi penyalahgunaan dan peredaran gelap narkoba yakni UU Narkotika. ${ }^{19}$ Sanksi terhadap tindak pidana penyalahgunaan narkotika mengacu pada double track system, artinya sanksi yang dapat dikenakan terhadap tindak pidana narkotika tidak hanya terbatas pada sanksi pidana, namun dapat pula dikenakan sanksi tindakan. Sanksi tindakan yang dimaksud yakni sanksi rehabilitasi yang ditunjukkan khusus

${ }^{14}$ Dani Krisnawati, D., M., Krisnawati, D., Utami, N. S. B., M., \& Subekti, N. (2014). Pelaksanaan Rehabilitasi Bagi Pecandu narkotika Pada Tahap Penyidikan Pasca Berlakunya Peraturan Bersama 7 (Tujuh) Lembaga Negara Republik Indonesia. Laporan Hasil Penelitian. h. 12

15 Dewi, C., \& Mas, A. I., Op. Cit, h. 8

16 Sujono, A. R., \& Daniel, B. (2011). Komentar \& Pembahasan Undang-Undang Nomor 35 Tahun 2009 tentang Narkotika. Sinar Grafika. Jakarta. h. 117-118

${ }^{17}$ Effendi, T. (2013). Sistem Peradilan Pidana Perbandingan Komponen dan Proses Sistem Peradilan Pidana di Beberapa Negara. Pustaka Yustisia. Yogyakarta. h. 147

18 Anggraeny, K. D. (2016). Disparitas Pidana Dalam Putusan Hakim Terhadap Tindak Pidana Psikotropika di Pengadilan Negeri Sleman. Jurnal Hukum Novelty, 7(2), h. 226

19 Hikmawati, P. Op. Cit. h. 340 
bagi pencandu narkotika. ${ }^{20}$ Namun dalam kenyataannya hakim sering kali tidak memberikan hak kepada pengguna narkotika untuk melaksanakan rehabilitasi, walaupun dalam UU Narkotika ada jaminan rehabilitasi bagi pencandu narkotika dan korban penyalahgunaan narkotika.

Sebagaimana dalam Ketentuan Pidana dalam Pasal 127 UU Narkotika yang menyatakan :

(1) Setiap penyalah guna:

a. Narkotika golongan I bagi diri sendiri dipidana dengan pidana penjara paling lama 4 (empat) tahun;

b. Narkotika golongan II bagi diri sendiri dipidana dengan pidana penjara paling lama 2 (dua) tahun; dan

c. Narkotika golongan III bagi diri sendiri dipidana dengan pidana penjara paling lama 1 (satu) tahun.

(2) Dalam memutus perkara sebagaimana dimaksud pada ayat (1) hakim wajib memperhatikan ketentuan sebagaimana dimaksud dalam Pasal 54, Pasal 55 dan Pasal 103.

(3) Dalam hal penyalahguna sebagaimana dimaksud pada ayat (1) dapat dibuktikan atau terbukti sebagai korban penyalahguna narkotika, penyalahguna tersebut wajib menjalani rehabilitasi medis dan rehabilitasi sosial.

Putusan Pengadilan Militer III-14 Denpasar Nomor: 33-K/ PM.III-14/AD/VIII/2015, yang menyatakan terdakwa yaitu Satriya Wira Yudha, Serda NRP 21120131370492, telah terbukti secara sah dan meyakinkan bersalah melakukan tindak pidana "Penyalah Guna Narkotika Golongan 1 bagi diri sendiri". Sebagai mana di ataur dalam pasal 127 ayat (1) huruf (a) Undang-Undang Nomor 35 Tahun 2009 tentang Narkotika, memidana terdakwa dengan pidana penjara selama 10 (sepuluh) bulan, dengan pertimbangan hakim sebagai berikut bawa apabila ketentuan pasal 127 ayat (1) UU Narkotika dan Surat Edaran Mahkamah Agung Nomor 4 Tahun 2010 tersebut dihubungkan dengan fakta-fakta yang terungkap dipersidangan ternyata terdakwa telah mengkonsumsi zat terlarang setelah Terdakwa tes urine dan darah bukan karena tertangkap tangan, Terdakwa mengkonsumsi obat terlarang tersebut dari pemberian Saksi- 5 Serka Anditiya Prima Wiguna di dalam mobil ketika perjalanan ke gili manuk, terdakwa mengaku baru pertama kali mengkonsumsinya dan dalam persidangan terdakwa nampak sehat meski telah tidak mengkonsumsi obat terlarang tersebut. Oleh karena itu Majelis hakim berpendapat terdakwa bukanlah pecandu sehingga tindak perlu menjalani rehabilitasi medis ataupun rehabilitasi sosial sebagaimana di tentukan dalam Pasal 127 ayat (2) Jo Pasal 54 Jo Pasal 103 UU Narkotika.

Pertimbangan hakim tersebut diatas dalam memutus perkara yang disebutkan dalam Pasal 127 UU Narkotika, tidak memperhatikan ketentuan Pasal 127 ayat (3) UU Narkotika. Padahal di persidangan diperoleh fakta, berdasarkan keterangan Saksi- 3 Sertu I Made Alit Prawira, Saksi- 5 Serka Adhitya Prima Citra Wiguna dan Saksi- 4 Sertu Mardita, mengatakan Saksi- 5 yang mengambil pil warna putih kehijauan dari saku celanya kemudian menarik rahang terdakwa dari belakang sambil bicara "buka mulutmu satrya" kemudian memasukan pil tersebut ke mulut terdakwa, namun terdakwa menolaknya karena curiga pil tersebut narkoba. Namun Saksi- 5 sambil

${ }^{20}$ Krisnawati, D. \& Utami, S. B., Op. Cit. h. 12 
marah "mengatakan sudah minum saja", akhirnya terdakwa menerima pilt tersebut lalau menelannya.

Berdasarkan Fakta persidangan terdakwa terbukti mengkonsumsi narkoba dalam keadaan terpaksa karena di bawah tekanan Saksi- 5, sebagaimana dalam penjelasan Pasal 54 UU Narkotika yang dimaksud dengan Korban penyalahgunaan narkotika adalah seseorang yang tidak sengaja menggunakan narkotika karena dibujuk, diperdaya, ditipu, dipaksa, dan/atau diancam untuk menggunakan narkotika. Ketika melihat penjelasan tersebut terdakwa bisa dikategorikan sebagai korban penyalahgunaan narkotika, dalam hal penyalahguna dapat dibuktikan atau terbukti sebagai korban penyalahguna narkotika, penyalahguna tersebut wajib menjalani rehabilitasi medis dan rehabilitasi sosial sebagaimana ketentuan Pasal 127 ayat (3) UU Narkotika. Ketentuan tersebut di perkuat dengan Pasal 54 UU Narkotika yang menyatakan pecandu narkotika dan korban penyalahgunaan narkotika wajib menjalani rehabilitasi medis dan rehabilitasi sosial.

Melihat ketentuan Pasal 127 ayat (2) dan (3) UU Narkotika, dapat disimpulkan bahwa hakim dalam memutus perkara yang disebutkan dalam Pasal 127 ayat (1) diwajibkan untuk memperhatikan pasal-pasal yang mengatur ketentuan rehabilitasi sehingga nantinya para pecandu dan korban penyalah guna narkotika dapat dijatuhi sanksi rehabilitasi baik rehabilitasi medis maupun rehabilitasi sosial dan tidak lagi dipidana penjara maupun pidana kurungan karena sanksi rehabilitasi tersebut dihitung sebagai masa menjalani hukuman. ${ }^{21}$ Mengingat teori pemidanaan yaitu penjatuhan pidana semata-mata karena seseorang telah melakukan suatu kejahatan atau tindak pidana. Menurut teori ini, hukuman itu dijatuhkan sebagai pembalasan terhadap para pelaku karena telah melakukan kejahatan yang mengakibatkan kesengsaraan terhadap orang lain atau anggota masyarakat 22 .

Menurut Karl O. Christiansen mengidentifikasikan 5 (lima) ciri pokok dari teori pembalasan atau retributif ini, yakni:

1. The purpose of punishment is just retribution (tujuan pidana hanya sebagai pembalasan);

2. Just retribution is the ultimate aim, and not in itself a means to any other aim, as for instance social welfare which from this point of view is without any significance whatsoever (pembalasan ialah tujuan utama dan di dalamnya tidak mengandung sarana-sarana untuk tujuan lain seperti kesejahteraan masyarakat);

3. Moral guilt is the only qualification for punishment (kesalahan moral sebagai satusatunya syarat untuk pemidanaan);

4. The penalty shall be proportional to the moral guilt of the offender (pidana harus disesuaikan dengan kesalahan si pelaku);

5. Punishment point into the past, it is pure reproach, and it purpose is not to improve, correct, educate or resocialize the offender (pidana melihat ke belakang, ia sebagai pencelaan yang murni dan bertujuan tidak untuk memperbaiki, mendidik, dan meresosialisasi pelaku ${ }^{23}$.

${ }^{21}$ Diputra, I. B. P. S. Op. Cit. h. 11

${ }^{22}$ Marpaung, L. (2005)., Asas-Teori-Praktik Hukum Pidana. Sinar Grafika. Jakarta. h. 4

${ }^{23}$ Christiansen, K. O. (1974). Some Consideration on the Possibility of a Rational Criminal policy. Resource Material Series, (7). p. 69 
Berkaitan permasalahan yang dibahas kaitannya dengan Putusan Pengadilan Militer III-14 Denpasar Nomor :33-K/ PM. III-14/AD/ VIII /2015, hakim yang menjatuhkan pidana penjara 10 (sepuluh bulan) bulan kepada terdakwa yaitu berpijak kepada ketentuan pasal 127 ayat (1) UU Narkotika dan Surat Edaran Mahkamah Agung Nomor 4 Tahun 2010 apabila di kaji menurut pendapat Karl O. Christinsen yang mengidentifikasikan 5 (lima) ciri pokok dari teori pembalasan atau retributif yang salah satunya yaitu The penalty shall be proportional to the moral guilt of the offender, menurut penulis penjatuhan pidana penjara tersebut di rasa berat, karena penjatuhan pidana harus di sesuaikan dengan kesalahan si pelaku.

Dengan memperhatikan bahwa sebagian besar narapidana atau tahanan kasus narkotika adalah masuk kategori atau bahkan sebagai korban yang jika dilihat dari aspek kesehatan mereka sesungguhnya orang-orang yang menderita sakit, oleh karenanya memenjarakan yang bersangkutan bukanlah langkah yang tepat. Kerangka yuridis yang telah ada di dalam UU Narkotika seharusnya digunakan oleh hakim dalam memutus pecandu dan pemakai narkoba yakni Pasal 127 UU Narkotika. Menempatkan penyalah guna/pengguna narkotika ke dalam lembaga rehabilitasi melalui putusan hakim merupakan alternatif sanksi pidana yang baik. ${ }^{24}$ Sebagai alternative lain, juga diusulkan model yang ideal yaitu si korban narkotika sendiri mengajukan permohonan untuk direhabilitasi.

Ahmad Kamil mengemukakan, bahwa hakim Indonesia harus mampu merefleksikan setiap teks pasal terkait dengan fakta kejadian yang ditemukan di persidangan ke dalam putusan hakim yang mengandung aura nilai Pancasila dan Undang-Undang Dasar Negara Republik Indonesia Tahun 1945, sehingga setiap putusan hakim memancarkan pertimbangan nilai filosofis tinggi, konkritnya ditandai oleh karakter putusan yang berketuhanan, berperikemanusiaan, menjaga persatuan, penuh kebijakan, dan berkeadilan sosial bagi seluruh rakyat Indonesia. ${ }^{25}$ Putusan hakim yang berkualitas merupakan putusan yang di dasarkan dengan pertimbangan hukum sesuai fakta yang terungkap di persidangan, sesuai undang-undang dan keyakinan hakim tanpa terpengaruh dari berbagai intervensi eksternal dan internal sehingga dapat dipertanggungjawabkan secara professional kepada publik.

\section{Kesimpulan}

Berdasarkan pembahasan yang telah diuraikan sebelumnya maka dapat disimpulkan, bahwa pertimbangan hakim Pengadilan Militer III-14 Denpasar melalui putusannya Nomor :33-K/ PM. III-14/AD/ VIII /2015, yang menyatakan terdakwa yaitu Satriya Wira Yudha, Serda NRP 21120131370492, telah terbukti secara sah dan meyakinkan bersalah melakukan tindak pidana "Penyalah Guna Narkotika Golongan 1 bagi diri sendiri". Sebagai mana di ataur dalam pasal 127 ayat (1) huruf (a) Undang-Undang Nomor 35 Tahun 2009 tentang Narkotika, memidana terdakwa dengan pidana penjara selama 10 (sepuluh) bulan. Bahwa Pertimbangan hakim tersebut tidak sesuai dengan ketentuan dalam Undang-Undang Nomor 35 Tahun 2009 tentang Narkotika karena hakim tidak memperhatikan ketentuan Pasal 127 ayat (3) Undang-Undang Nomor 35 Tahun 2009 tentang Narkotika yang menyatakan dalam hal penyalahguna

${ }^{24}$ Hikmawati, P. Op. Cit. h. 344

${ }^{25}$ Ahmad Kamil, 2012, Filsafat Kebebasan Hakim, Kencana, Jakarta, h. 306 
sebagaimana dimaksud pada Pasal 127 ayat (1) dapat dibuktikan atau terbukti sebagai korban penyalahguna narkotika, penyalahguna tersebut wajib menjalani rehabilitasi medis dan rehabilitasi sosial. Ketentuan tersebut di perkuat dengan Pasal 54 UU Narkotika yang menyatakan pecandu narkotika dan korban penyalahgunaan narkotika wajib menjalani rehabilitasi medis dan rehabilitasi sosial. Oleh karena itu hakim dalam menjatuhkan putusan terhadap pelaku penyalah guna narkotika harus berpedoman pada ketentuan yang sudah diatur dalam Undang-Undang Nomor 35 Tahun 2009 tentang Narkotika.

\section{Daftar Pustaka}

Buku

Adi, K. (2009). Kebijakan Kriminal dalam penanggulangan tindak pidana narkotika oleh anak. Malang: UMM Press.

Amrani, H., \& Ali, M. (2015). Sistem Pertanggungjawaban Pidana Perkembangan dan Penerapan. Jakarta: Raja Grafindo Persada.

Atmasasmita, R. (2010). Sistem Peradilan Pidana Kontemporer. Jakarta: Kencana.

Christiansen, K. O. (1974). Some Consideration on the Possibility of a Rational Criminal policy. Resource Material Series.

Marpaung, L. (2005). Asas-teori-praktik hukum pidana. Jakarta: Sinar Grafika.

Salim, H. S., \& Nurbani, E. S. (2014). Penerapan Teori Hukum Pada Penelitian Disertasi dan Tesis. Jakarata: PT Raja Grafindo Persada,.

Effendi, T. (2013). Sistem Peradilan Pidana Perbandingan Komponen dan Proses Sistem Peradilan Pidana di Beberapa Negara. Yogyakarta: Pustaka Yustisia.

Jurnal

Anggraeny, K. D. (2016). Disparitas Pidana Dalam Putusan Hakim Terhadap Tindak Pidana Psikotropika di Pengadilan Negeri Sleman. Jurnal Hukum Novelty, 7(2), 225-236

Artha, I. G., \& Wiryawan, I. W. (2015). Pengendalian Peredaran Gelap Narkotika Oleh Narapidana Dari Dalam Lembaga Pemasyarakatan (Lapas). Jurnal Magister Hukum Udayana (Udayana Master Law Journal).4(3). 588-602. https://doi.org/10.24843/JMHU.2015.v04.i03.p14

Dewi, C., \& Mas, A. I. (2012). Perlindungan Hukum terhadap Korban Penyalahguna Narkotika dengan Berlakunya Undang-undang Nomor 35 Tahun 2009 Tentang Narkotika. Jurnal Magister Hukum Udayana, 1(1), 1-22. https://doi.org/10.24843/JMHU.2012.v01.i01.p01

Diputra, I. B. P. S. (2013). Kebijakan Rehabilitasi Terhadap Penyalah Guna Narkotika Pada Undang-Undang Nomor 35 Tahun 2009 Tentang Narkotika. Jurnal Magister Hukum Udayana (Udayana Master Law Journal). 2(1). 1-16. https://doi.org/10.24843/JMHU.2013.v02.i01.p10 
Eleanora, F. N. (2018). Bahaya Penyalahgunaan Narkoba Serta Usaha Pencegahan Dan Penanggulangannya (Suatu Tinjauan Teoritis). Jurnal hukum, 25(1), 439-452.

Isnaini, Y., Hariyono, W., \& ken Utami, I. (2013). Hubungan antara dukungan keluarga dengan keinginan untuk sembuh pada penyalahguna NAPZA di lembaga pemasyarakatan wirogunan kota yogyakarta. Kes Mas: Jurnal Fakultas Kesehatan Masyarakat, 5(2).

Sholihah, Q. (2015). Efektivitas Program P4GN Terhadap Pencegahan Penyalahgunaan NAPZA. Jurnal Kesehatan Masyarakat, 10(2), 153-159.

Gani, H. A. (2015). Rehabilitasi sebagai Upaya Depenalisasi Bagi Pecandu Narkotika. Kumpulan Jurnal Mahasiswa Fakultas Hukum.

\section{Laporan Penelitian}

Dani Krisnawati, S. H., Hum, M., Krisnawati, D., Utami, N. S. B., Sh, M., \& Subekti, N. (2014). Pelaksanaan Rehabilitasi Bagi Pecandunarkotika Pada Tahap Penyidikan Pasca Berlakunya Peraturan Bersama 7 (Tujuh) Lembaga Negara Republik Indonesia. Laporan Hasil Penelitian.

Hikmawati, P. (2011) Analisis Terhadap Sanksi Pidana Bagi Pengguna Narkotika. Peneliti Madya Bidang Hukum Pidana pada Pusat Pengkajian Pengolahan Data dan Informasi (P3DI) Setjen DPR RI. Jakarta

\section{Peraturan Perundang-undangan}

Kitab Undang-Undang Hukum Pidana (KUHP)

Undang-Undang Republik Indonesia Nomor 35 Tahun 2009 Tentang Narkotika, Lembaran Negara Republik Indonesia Tahun 2009 Nomor 143, Tambahan Lembaran Negara Republik Indonesia Nomor 5062 